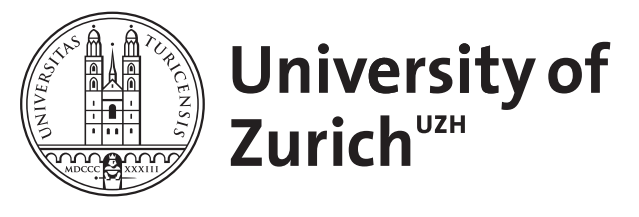

\title{
Making international organizations more democratic
}

\author{
Stutzer, Alois ; Frey, Bruno S
}

\begin{abstract}
World governance today is characterized by international organizations lacking democratic legitimacy and control by the citizens they claim to represent. They are also criticized for being inefficient. This leads to violent protests and to NGOs having great influence. To address these problems, we propose international governance based on the democratic idea of citizen participation: All citizens of the member countries of international organizations have the potential right to participate in the decision-making of international organizations via initiatives, referendums and recalls. In order to reduce transaction costs, a representative group of citizens is randomly selected who can actually exercise their participation rights
\end{abstract}

DOI: https://doi.org/10.2202/1555-5879.1018

Posted at the Zurich Open Repository and Archive, University of Zurich ZORA URL: https://doi.org/10.5167/uzh-154331

Journal Article

Published Version

Originally published at:

Stutzer, Alois; Frey, Bruno S (2006). Making international organizations more democratic. Review of Law and Economics, 1(3):305-330.

DOI: https://doi.org/10.2202/1555-5879.1018 


\title{
Making International Organizations More Democratic
}

\author{
ALOIS STUTZER, BRUNO S. FREY* \\ University of Zurich
}

World governance today is characterized by international organizations lacking democratic legitimacy and control by the citizens they claim to represent. These organizations are also often criticized for being inefficient. This has led to violent protests and to NGOs having great influence. To address these problems, we propose international governance based on the democratic idea of citizen participation: All citizens of the member countries of international organizations have the potential right to participate in the decision-making of international organizations via initiatives, referendums and recalls. In order to reduce transaction costs, a representative group of citizens is randomly selected who can actually exercise their participation rights.

\section{PROBLEMS WITH GLOBAL GOVERNANCE}

Many institutions in the area of global governance are confronted time and again with public protests. In particular, the meetings of international organizations such as the IMF, the WTO and the World Bank, and of private organizations, such as the World Economic Forum, have been attacked frequently by large-scale and violent protests. These protests get substantial coverage by the media; often as much time and space is allocated to reporting on the demonstrations and demonstrators as to the issues under debate at the official meetings.

The major charge brought against the institutions involved in international governance is that they favor "unjust" solutions to the world's problems. The

\footnotetext{
* We wish to thank Matthias Benz, Robert Cooter, Christoph Engel, Laurent Franckx, Henry Hansmann, Gérard Hertig, Simon Lüchinger, participants at the European Public Choice Meeting 2004, and an anonymous referee for their valuable comments..
} 
protesters complain about these institutions' neglect of the poor and are convinced that globalization raises, rather than diminishes, the number of people living in poverty. ${ }^{1}$ They also blame these institutions for neglecting environmental degradation. International organizations have, moreover, been accused of large-scale inefficiency and waste, and of being ineffective in the sense of not being able to put policies into action or enforce them. Still others complain about the "democratic deficit" of international organizations and deny the legitimacy of many representatives of the so-called global civil society involved in international governance. It is argued that, rather than reflecting "world opinion," they represent the specific interests of the donors who fund NGO activities.

Several reasons have been found to account for these failures: First, taxpayers of the nations funding the international organizations (the principals) do not effectively and sufficiently control the behavior of bureaucrats in international organizations (the agents). Second, international agreements involve the provision of public goods and thus provide incentives for free riding. This problem is aggravated because external enforcement of agreements is very limited between sovereign states. Third, the delegation of competencies to international organizations and their policy-making under current forms of democracy do not meet adequate procedural conditions to ensure that people in member countries feel like empowered citizens with autonomy and influence. Instead, current rules and regulations make international organizations susceptible to the influence of the governments of single member countries, business interests, and NGOs. ${ }^{2}$

Many solutions have been offered on how to improve global governance and to overcome the specific problems identified. One solution is to increase transparency so that the people concerned have a better knowledge of how the various policies proposed, and actually carried out, are going to affect them. Another solution is to tighten the rules, standards and criteria under which international institutions act. While these measures are useful, they are certainly

\footnotetext{
${ }^{1}$ Whether this is indeed true is another matter. For the view that globalization is good for the poor, see e.g. Dollar and Kraay (2004).

2 Hewson and Sinclair (1999), Nye and Donahue (2001), Kahler and Lake (2003), Kaul et al. (2003) and the Commission on Global Governance (1995) provide an extensive list of references to the literature on globalization, transnational relations, international regimes and international organizations. On the global civil society, see e.g. Keane (2003) or Glasius et al. (2002). For recent contributions on global governance, see e.g. Held (1997), Walzer (1998), Barnett and Finnemore (1999), Pierre (2000), Keohane and Nye (2000), Keohane (2001), and Heritier (2002). The literature in economics is more restricted; see e.g. Vaubel and Willett (1991), Frey and Gygi (1990, 1991), Frey (1984, 1997d), Schulze and Ursprung (1999) and Rodrik (2000).
} 
not sufficient to overcome the failures in international governance already alluded to. A far-reaching proposal would be to establish a World Government. As it would cover the entire globe, it would be considered capable of providing global public goods in an optimal way, and of reducing, or even preventing, global public bads. It would also be expected to overcome the inequality existing in today's world.

However, there are major arguments against a global government. In fact, it may not even be desirable. A global government must, by necessity, be a large bureaucratic organization, which would, if anything, be even more inefficient and wasteful than the existing international organizations. But even more importantly, individuals would be totally dependent on this new government. Persons who did not agree with its policies, or who felt oppressed due to a lack of freedom or too high and unjust taxes, would have no possibility of escape by migrating elsewhere. "Exit" would thus be impossible, which would rob dissenting people of the important possibility of making their dissatisfaction visible to the political decision-makers (Hirschman, 1970). The leaders of the global government would hold unprecedented power in their hands. As has often been remarked, and rightly so, absolute power corrupts absolutely, and there is no reason why this should not apply to a global government. However, it is highly unlikely that such a government will evolve in the foreseeable future, because the nation states dominating the present world, in particular the United States, cannot reasonably be expected to relinquish even small parts of their power in favor of a global government.

We propose a different approach to international and world governance based on the fundamental democratic idea of citizen participation. While we are convinced that this proposal could fundamentally change world governance as it exists today, we would restrict it to improving the functioning of international organizations. ${ }^{3}$

Our proposal is based on two fundamental design elements:

(1) All citizens of all member countries of a particular international organization should have potential participation rights in international political decision-making.

(2) All citizens should have the same chance of being selected to actually have the possibility to vote.

\footnotetext{
${ }^{3}$ But our proposal could also be used beyond international organizations, in particular for new forms of public governance, such as the establishment of functional, overlapping and competing jurisdictions (so-called FOCJ). These are discussed briefly in section 5.
}

DOI: $10.2202 / 1555-5879.1018$ 
The first element refers to the advantages of democratic decision-making as a complement to the hierarchical decision-making process already in place in international organizations. Citizen participation is put forward as a political right enshrined in the "constitution" of an international organization. Participation rights would consist of three democratic instruments: (i) Citizens could propose changes to the ground rules (or constitution) of the organization. If enough citizens were to sign a popular initiative, the proposal would have to be put on the voting agenda, and would become a binding rule if approved in a ballot held in all member countries. (ii) Fundamental changes in the ground rules, or extensions of international agreements, would have to be approved in a mandatory referendum. ${ }^{4}$ (iii) Second priority would be given to a further extension of citizen participation that would include the recall of top bureaucrats in international organizations. In this proposal, citizens' participation rights would not include elections. The appointment of top public officials in international organizations would stay as it is at present. This would allow public discourse to focus more on issues dealing with content rather than on candidates coming from the "right" nation.

Citizens' involvement would thus be understood as direct democratic participation. There is extensive knowledge in political science, law and economics about the working of direct democracy at the state and federal level. ${ }^{5}$ While there are international organizations of a size comparable to that of a U.S. state with regard to the population of their member countries, there are also numerous organizations representing many more people. Conducting referendums with a citizenry of a billion people is barely manageable and produces high transaction costs.

We therefore propose a second design element that introduces a mechanism to reduce the number of people who will actually get the possibility of participating as voters. This can be achieved by using the principle of random selection among all the citizens of the member countries. The term "random" in everyday usage is associated with terms such as aimless, haphazard, uncertain, or indifferent. Here the word is used, as in statistics, where a random sample gives each and every member of the population the same probability of being selected. Random selection thus means that each citizen of a member country in an international organization has an equal chance of being chosen. He or she

\footnotetext{
${ }^{4}$ Alternatively, a referendum could only be held if required by a certain number of citizens or member countries. Mandatory referendums would, in certain cases, replace ratification by national parliaments.

${ }^{5}$ For reviews of the literature, see e.g. Bowler and Donovan (1998), Frey and Stutzer (2006), Gerber and Hug (2001), Kirchgässner et al. (1999), and Matsusaka (2004).
} 
is, in this sense, a precise representative of the underlying aggregate citizenship. The basic democratic idea is that each person is capable of making a useful contribution to political decision-making, just as every citizen in a representative democracy has the power to vote, regardless of his or her income, education, gender, religion or race.

As we envisage the main novelty in the second design element, we focus on the aspect of random selection. We expect four improvements as a result of our proposal:

(1) International organizations would allow effective citizen participation in decision-making on issues of content;

(2) Efficiency would be raised by effectively controlling the executive politicians and public officials in international organizations.

(3) The influence of special interests in international governance would be weakened relative to latent groups and would be channeled within the rule of law.

(4) Collective decisions would become more self-enforcing, due to the strengthened legitimacy of international agreements.

The next section of this paper discusses the institutional design of random selection and direct political participation in international organizations. Section 3 lists the advantages and disadvantages of our proposal. The following section 4 shows that random selection is and has been not uncommon in political decision-making, and that there are other proposals taking advantage of the qualities of random selection. Section 5 compares the random selection of citizens to other proposals for improving global governance. Section 6 offers concluding remarks.

\section{INSTITUTIONAL DESIGN: DIRECT POLITICAL PARTICIPATION OF RANDOMLY SELECTED VOTERS}

We propose to overcome the insufficient democratic foundation and efficiency of international organizations by empowering the citizens of member states to have a say in the decisions made. In order to deal with the frequently considerable number of citizens involved, the voting body is reduced to a size allowing voting to proceed in a manageable manner. This is achieved by selecting a restricted number of persons via a random mechanism, giving each

DOI: $10.2202 / 1555-5879.1018$ 
person the same chance of being chosen. The randomly selected citizens are given the right to vote on issues of content by means of popular initiatives and referendums, and by recalling the international organization leaders in cases where they disapprove of their performance.

\subsection{RANDOM SELECTION}

Using the random mechanism to select from among all citizens those who will have actual voting rights represents a constitutional choice ${ }^{6}$ behind the veil of ignorance between the many possible social decision-making procedures. The best-known procedures of this kind are the market, democracy, hierarchy and bargaining, but there are others, such as decisions made according to tradition (Dahl and Lindblom, 1953). The constitutional approach is procedural or process-oriented; it does not consider particular outcomes, but looks at the way decisions are reached. Decision-making mechanisms are chosen so that, in the long run, given people's interests in the current political process, people's preferences are best satisfied. Thereby, people have preferences about the process as such and experience procedural utility beyond the utility from the outcome reached (for a survey, see Frey et al., 2004). The procedural good of central importance for democracy is that ordinary people, rather than a selfselected elite, make the ultimate decisions in international organizations. Empirical research indeed suggests that the possibility of participation provides procedural utility, independent of outcome utility. ${ }^{7}$

\subsection{RANDOM SELECTION OF VOTERS}

Basis of Representation. A selection corresponding most closely to the standard understanding of democracy assigns equal weight to each citizen of the member states. In that case, the larger a country's population, the greater its influence. However, an alternative possibility would be to assign the number of selected voters according to financial contributions (as in the case of the World Bank and the IMF), or to select an equal number from each country (similar to the one-country, one-vote rule in the UN General Assembly). Which assignment is chosen depends on a large number of factors. If, for instance, small member countries want to be protected from potential exploitation, the

\footnotetext{
${ }^{6}$ Constitutional choice is extensively discussed in Buchanan and Tullock (1962), Frey (1983), Brennan and Buchanan (1985), Mueller (1996), and Cooter (2000).

${ }^{7}$ The respective econometric analysis has been undertaken using self-reported subjective wellbeing data in a cross-section over the 26 cantons of Switzerland, which grant their citizens unequal political participation possibilities (Frey and Stutzer, 2005).
} 
same number of citizens should be selected from each country to decide on referendums.

Random selection may in practice be undertaken by using any appropriate mechanical system (such as using lots) or by using computer programs. The underlying population from which the citizens are selected may be taken from the voter rolls of those countries which are members of the particular international organization, assuming that these countries are (at least in a formal sense) democracies.

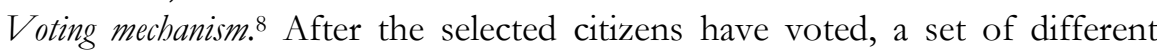
decision rules is possible. Using simple majority is a natural starting point. However, the status quo, which represents at least a previous social consensus, might best be protected with the requirement of a qualified majority. In order to protect minority interests, it would also be possible to demand double majority, i.e. a majority of votes, as well as a majority of countries that approve a proposal.

Conditions of selection. Most importantly, the term in office has to be decided. The shorter the term, the larger the number of preferences represented via random selection. However, this has the disadvantage that the selected citizens are less capable of informing themselves about the activities of the particular international organization. Thus, the more important experience and factual knowledge are in decision-making, the longer the term of office should be.

A selected citizen may be associated with one particular international organization or with various international organizations. The more similar the activities of international organizations are, the more sense it makes to select voters who will serve for several organizations.

Anonymity. The identity of the selected citizens can be made public or can be kept secret. Publicity enables other citizens to make their concerns felt to their selected fellow citizens, but also gives pressure groups the possibility of influencing them, putting non-organized groups at a disadvantage (Olson, 1965). In many cases, the pressure exerted by the national governments is even more relevant. However, as the national administrations apply the random selection mechanism and have to decide whether to publicize which citizens have been selected, the identity of the representatives cannot be easily hidden from the national governments. In view of this, there is much to be said for

\footnotetext{
${ }^{8}$ We do not discuss different technically possible voting mechanisms, such as e-voting, here. The organization of the vote is left to the individual member countries. We do not suggest evoting in our proposal, because security issues with e-voting have not yet been dealt with sufficiently--it is probably far easier to manipulate e-voting than voting at the ballot box. Moreover, the transaction costs of voting are probably a minor determinant of the quality of decisions.
}

DOI: $10.2202 / 1555-5879.1018$ 
making the identity of the representatives known. Rules may be introduced limiting the undue influence of pressure groups. In particular, both active and passive corruption must be punished.

\subsection{Citizens' Participation RightS}

The citizens selected by lot can exercise their rights in two different ways:

(1) They can initiate votes on issues of content (initiatives) or on people (recall). Both a successfully launched initiative and a recall force the managers of the international organization concerned to hold a vote among all the citizens selected. Whether such votes are frequent or rare is to a large extent determined by the signature requirement. The signature requirement can be defined as a total minimum number across nations. However, it can also include minimum numbers of signatures within a percentage of countries, or restrictions as to the maximum duration of time between the point at which an initiative/recall is announced and the point at which the signatures are deposited. ${ }^{9}$

(2) They can vote in a mandatory referendum applicable to major issues, such as changes in the ground rules (the constitution) of the international organization.

The content of initiatives is not restricted; however, proposals must be made for changes to the constitution of an international organization. Recall of the management of an international organization can be applied to politicians and public officials. Assigning a signature quorum faces a trade-off. The lower the quorum number, the larger the uncertainty among the managers, inducing them to take a short-term view. The higher the quorum, the stronger the position of the managers. The less discretionary room the managers have, the less threatening is such management power to the interests of the citizens of the member states. In some cases, the tasks of international organizations are so precisely defined that managers are severely restricted. If that happens, the quorum for recall may well be high. In other cases, the managers are, to a large extent, able to determine the organization's activities by themselves, in which case a stricter restriction on the threat of recall is desirable.

\footnotetext{
${ }^{9}$ Alternatively, signing an initiative or a recall can be allowed to every citizen, whether selected or not. In this case, signature requirements should be substantially increased.
} 
Making International Organizations More Democratic / 313

\subsection{ApPliCATION TO THE UNITED NATIONS}

The United Nations (UN) is in a crisis. Many of the alleged grievances are not new, including bureaucratic slowness, ineffectiveness and even corruption. More fundamental is the UN's incapacity to reform itself and to change its ground rules in order to fulfill its mission to "save succeeding generations from the scourge of war." A prime deadlock lies in the anachronistic Security Council. Of its 15 members, five permanent members (the four main victors in the Second World War - the United States, Russia, Great Britain and China plus France) have veto power over all important UN decisions (including the composition of the Security Council itself). This distribution of power in the $\mathrm{UN}$ is not at all representative of the reality of international politics today, nor is it in any sense democratic. As a consequence, UN decisions-or more often non-decisions-lose legitimacy and the $\mathrm{UN}$ is far from being the moral authority it needs to be in order to successfully protect freedom and support democratic nation building. The deadlock is probably due not only to the privileged position of the permanent members, but also to the challenger's policy that contributes to the deadlock, thus undermining the UN's authority. ${ }^{10}$

According to our proposal, citizens would have the right to initiate an amendment to the UN charter and thus set the agenda. This would allow the people to break the deadlock that is endangering a potentially great institution. Citizens interested in peace-rather than politicians involved in local rivalries with neighboring nations for seats in the Council-could collect signatures for a proposal. The proposal's content is not restricted and could, for example, comprise a rotating Security Council, making decisions based on a qualified majority, and being accountable to the remaining UN member countries. The UN would then arrange a vote in which all selected citizens in the member countries could participate. If the initiative were to be approved in a majority of countries and by a majority of voters, the proposed amendment would become binding for the UN.

\section{EVALUATION OF THE PROPOSAL}

Selecting voters randomly from the population of citizens of the member countries belonging to an international organization has several important advantages over other ways of approaching the issue. We first discuss the

10 On the one side, Germany, Brazil, India and Japan are supporting each other for a permanent seat in the Security Council while, on the other side, there are opponents to an enlargement because they do not want their neighboring country to have more power. The latter group includes Italy, Spain, Pakistan, South Korea, Argentina and Mexico.

DOI: $10.2202 / 1555-5879.1018$ 
advantages and disadvantages of random selection in general, and then evaluate our more specific proposal for its application to international organizations.

\subsection{AdVANTAGES AND DisADVANTAGES OF THE RANDOM MECHANISM}

As is true for all social decision-making mechanisms, random selection has its strengths and weaknesses. Only the most important ones are mentioned here (for a fuller discussion see Carson and Martin (1999:34-38) and Elster (1989:103-122)).

Major advantages are:

- Random selection is fair in the sense that every person has an equal chance of being selected. ${ }^{11}$ If the random mechanism is correctly applied, no other consideration, such as income, status or political connections plays any role.

- The selection is totally representative as, after a number of draws, the persons chosen exactly reflect the underlying population of voters. No particular gender, race, religion or any other group is favored.

- Decisions by lot are easy to undertake and are universally applicable. A common method of deciding between two issues is to toss a coin. When there are more issues involved, balls are put into an urn, and then one or more of the balls is selected either mechanically or by a person (these procedures are well known from lotteries, and are regularly shown on TV).

There are also important actual or presumed disadvantages:

- The random method seems to lack "rationality," in the sense that no reason for a particular choice is given. But individuals seem to have an innate need to attribute a reason to a certain choice. Having no reason for a selection leaves a feeling of dissatisfaction. The interpretation of random mechanisms as being aimless, haphazard and indifferent derives from this.

- The persons chosen tend to have a reduced obligation to take the task they are chosen for seriously. Exactly because they are chosen indiscriminately, they can hardly pride themselves on having been selected because of their intelligence, dedication, efficiency or knowledge. As a result, the intrinsic motivation to perform well might be reduced (this is a kind of "crowdingout effect," see Frey (1997b)).

\footnotetext{
11 This holds, of course, only for draws with equal probabilities, which are the rule. But it is easily possible to assign a person, or group of persons, more weight, e.g. they are given two times or three times as much weight. But the argument continues in the sense that no other considerations enter into the matter.
} 
While this argument rings true, it is of lesser importance in reality than one might expect. Even purely randomly selected persons, after a short time, tend to attribute positive features to themselves, once they have been selected. At least to some extent, they believe that their choice has been "god's will" (an aspect crucial in Athenian democracy, see Elster (1989:5052)) or, in a secularized society, that it at least has some unknown deeper meaning behind it.

These advantages and disadvantages should not be considered in isolation. They need to be compared to the advantages and disadvantages any other social decision-making system has (following a comparative institutional analysis). This paper argues that the advantages of random selection are particularly strong for the selection of representative citizens to overview international organizations. While the disadvantages certainly cannot be dismissed, they are in this particular application reckoned to be of minor importance compared to the disadvantages of using other social decisionmaking mechanisms (see section 5).

\subsection{STRENGTHS OF INTERNATIONAL ORGANIZATIONS WITH RANDOMLY SELECTED VOTERS}

The most important argument in favor of the constitutional proposal is the strengthening of democratic control by the citizens. The democracy deficit now characterizing international organizations is overcome by giving citizens direct participation rights. As it would be complicated and time consuming to ask for everybody's vote, a representative group of citizens is randomly selected. These selected citizens have considerable power through the use of initiatives, referendums and recalls. This enables them to not only react to what the management of the international organizations proposes, but also to exert agenda-setting power. ${ }^{12}$

The democratization of international organizations gives them a measure of legitimacy which otherwise cannot be attained. The citizens of member countries, aware that they are fairly represented in international organizations' decision-making processes, are motivated to provide international public goods, or at least to politically support their provision. An example would be international agencies for the improvement of global environmental goods (such as combating global warming), which today are essentially technocratic units without much, or any, democratic basis, acting at a far remove from the

\footnotetext{
12 The crucial importance of agenda setting is discussed in McKelvey (1976) and Romer and Rosenthal (1978).
}

DOI: $10.2202 / 1555-5879.1018$ 
citizens. With a system of randomly selected voters connected to such organizations, the citizens of the various member countries could start to feel an incentive and obligation to participate in the joint effort. An important factor in creating this sense of participation would be the general discussion generated among citizens, whether they are selected or not. ${ }^{13}$ On the one hand, currently citizens are informed by NGOs mostly via the mass media (in particular TV and radio). On the other hand, with direct participation the citizens have an incentive to involve their representatives in discussions about the issues to be decided by the respective international organization. The public discourse from the grassroots level, as well as from specialists, serves to strengthen the willingness to participate in the provision of international public goods. ${ }^{14}$

Another important advantage of direct participation rights for citizens is the resulting bundling of decentralized information from below about the possibilities and constraints of the international organizations' activities. This information is less filtered and distorted than that coming from the organizations' bureaucracy, which tends to be biased by strategic considerations.

Recalls, as well as initiatives and referendums, are an effective means of controlling the management of the international organizations. This power can be exerted via the selected citizens and also by non-governmental organizations. They gain institutionalized access to making their demands heard. They are less induced, or even compelled, to go out on the streets and resort to violent action. Moreover, those non-state actors claiming to be the voice of the people have to convince the selected citizens as they gain relatively more influence.

Finally, decisions on international agreements taken by the citizenry gain substantial legitimacy. It becomes costly for single governments of member countries to step back due to short-term interests, although no direct enforcement of the agreements is possible. Not sticking to these agreements cannot easily be justified by too high costs for the population, if a majority of selected citizens actually approved them.

\footnotetext{
13 For the role of political discourse in multilateral organizations, see Verweij and Josling (2003).

14 See experimental results with public goods games, demonstrating that pre-play communication, even solely identification of the persons involved, strongly raises the willingness to contribute to the provision of public goods. See Bohnet and Frey (1999) and the extensive survey by Sally (1995). A cross-section econometric analysis for Swiss cantons suggests that the more extensive the citizens' direct participation rights are, the higher tax morale is, and therefore the lower tax evasion is (Pommerehne and Weck, 1996; Frey, 1997a). See also Torgler (2003).
} 
Making International Organizations More Democratic / 317

\subsection{PotentIAL WEAKNESSES}

As has already been pointed out, all social decision-making systems have disadvantages. This also holds for the random selection of citizens who have extended democratic participation rights in international organizations. But, as will be argued, many of these shortcomings are not as serious as they initially appear to be.

It may be argued that randomly selected citizens do not have the skills necessary to decide in a reasonable and effective way on the constitutional matters of international organizations. By definition, the selected citizens only have average education and may therefore be perceived to be ill prepared for the task. This argument goes to the roots of political decision-making. Democracy is based on the principle that the citizens, on average, are capable of making political decisions in a reasonable way. They have one great advantage over professional politicians and bureaucrats: they know their own preferences better and are therefore able to express them better politically. Moreover, there is the fundamental principal-agent problem in politics: the professional politicians should act in the interests of their principals, the citizens, but they only have limited incentives to do so. In a representative democracy, the professional politicians are responsive to the citizens' preferences, especially at election time. Empirical evidence demonstrates that, at other times, the actions undertaken by the professional politicians deviate substantially from the citizen's wishes. ${ }^{15}$ In the extreme, the politicians "exploit" the voters by pursuing policies according to their personal or party ideologies, follow the interests of well-organized and financially well-endowed pressure groups, or decide in their own favor (Brennan and Buchanan, 1980, 1985). For instance, they accord themselves special privileges (e.g., immunity from laws) or material benefits (such as generous compensations and pensions, sumptuous expense accounts, cars and planes at their free disposal). With direct participation rights of the citizens, these problems arise to a much lesser extent. Econometric studies have been able to show that citizens can make well-reasoned political decisions. Indeed, the more extensive citizens' direct participation rights are, the better the public economy is run. For instance, the relationship between public expenditures and revenue is better controlled, so that the public debt per capita is lower. It has also been shown that per capita income is higher because the public sector is better run, and that even selfreported subjective well-being is higher. ${ }^{16}$

\footnotetext{
15 See, e.g., the evidence on political business cycles in Frey (1997c) and Mueller (2003:part IV).

16 See Kirchgässner et al. (1999) and Frey and Stutzer (2000), as well as the literature mentioned in footnote 5 .
}

DOI: $10.2202 / 1555-5879.1018$ 
A related argument claims that randomly selected citizens are not well enough informed and are therefore at the mercy of bureaucrats. First of all, it must be said that the same applies even to professional politicians; public officials always have more information at their disposal, because they have often been in charge of particular issues for a much longer period of time. It should also be noted that randomly selected citizens tend to rise to the challenge and can collect the information necessary for making reasoned decisions. Such information need not be very detailed: what matters are the fundamental issues to be decided on. Citizens need to be able to draw on the knowledge of experts, whose job it is to provide detailed information. Moreover, empirical evidence shows that it would be a mistake to take the present level of information about the issues related to international organizations as a constant. Rather, the amount of information consumed is endogenously determined and is higher when citizens have more extensive political rights (Benz and Stutzer, 2004). It can thus be expected that the randomly chosen citizens are capable and willing to learn the information necessary to perform their task adequately.

It may also be claimed that randomly chosen representatives have little incentive to participate in the decision making of the international organization to which they are assigned to. But a high participation rate should not be taken as a value in itself. What matters is that the selected citizens participate in the initiatives, referendums and recalls when important issues are at stake. Such behavior provides clear signals to the management of international organizations that they are effectively controlled by the citizens and cannot simply do what is in their own interests. Most people will consider it an honor to be selected as a citizen with actual voting rights to an international organization, and will therefore have an incentive to participate.

Quite a different argument questions whether the people perceive the random selection of a group of citizens to be fair. In the private realm, there is indeed considerable resistance to random decisions. Several studies have analyzed the allocation of private goods in situations of shortage. In a survey among the population, the use of a random decision mechanism has been considered to be less fair than alternative social decision-making mechanisms such as "firstcome, first-served," an allocation by the commune, or even the use of a price system (Frey and Pommerehne, 1993; also Wortman and Rabinowitz, 1979; Erez, 1985). Such resistance where rationing is concerned certainly has to be taken into account. However, in the public sphere, resistance can probably be overcome by showing the citizens the advantages of random selection, in particular the guarantee that every citizen is treated equally. People can also be informed that random systems are used, and generally accepted, in many areas 
relating to their personal lives as, for instance, in the hugely popular national lotteries, where the mechanism used is extensively shown on primetime TV.

Another argument relates to the situation in those member countries with little or no democratic tradition. While the random mechanism can probably be controlled from outside, this is less likely to be the case for the underlying list of the electorate, and the communication of who has been selected. But, most importantly, the selected citizens in such a country will be induced, or forced directly, to follow the will of the country's government. This is unfortunate, but our proposal does not claim to be able to transform non-democratic governments into democratic governments. If indeed the representatives are forced to act as government pawns, the situation is no worse than today, where the delegates of international organizations are directly selected by the respective non-democratic governments. However, the random selection of citizens may even give them a measure of independence with respect to their own government, not least because they decide jointly with selected citizens in democratic countries. Such joint experiences may (under the most favorable conditions) even initiate a step towards democratization (Sen, 1999).

A final argument might be the hint offered by the largely failed experiment of running a globally representative decision-making body by ICANN. ${ }^{17}$ The Internet Corporation for Assigned Names and Numbers (ICANN) was founded in California in 1998 as a not-for-profit corporation based on an initiative of the U.S. government. ICANN was charged with the technical coordination of the Internet, including standard-setting, the allocation of toplevel domains and technical administration, i.e. involving significant regulatory functions. ICANN was understood to be an open and representative body accountable to the Internet community; however, it soon instead showed strong features of regulatory capture. ${ }^{18}$ This finally led to demand for the election of five of its 19 directors. In the fall of 2000, ICANN held a global online election, open to all Internet users. In fact, voting was only possible for those users who registered in advance to get a pin number by regular mail, which then allowed them access to the e-voting portal on the Internet. This procedure was very expensive and resulted in a low participation rate (calculated as a fraction of all Internet users). After disputes developed between the newly elected and the old board members, the experiment was ended when, on December 15, 2002, the elected directors' terms expired. This experience

\footnotetext{
${ }^{17}$ Illuminating analyses of the ICANN experiment with representative democracy are provided in Hunter (2003) and Palfrey (2004).

${ }^{18}$ For an economic analysis of ICANN's monopolistic position in the international governance of the Internet, see Brady (2003).
}

DOI: $10.2202 / 1555-5879.1018$ 
highlights that democratization as understood in the case of ICANN is very different from the direct political participation of selected voters which we have described. Thus ICANN's experience is not very useful to assess the practicality of our proposal. Our emphasis is on voting on issues rather than people. More importantly, in the ICANN case, democratic participation possibilities were specific and restricted to the election of a minority of directors in an otherwise complicated decision structure. From the very beginning, users' empowerment was rather limited and was not motivating of participation. Finally, while there is an argument for citizen participation in technical coordination, it is not where we would start promoting our proposal.

\section{RANDOM SELECTION: EXPERIENCES IN THE PAST AND PROPOSALS IN THE LITERATURE}

\subsection{PAST EXPERIENCES}

Current and past experiences show that the use of random selection is not outlandish. ${ }^{19}$ There are many examples where random procedures are used--for example, in games of chance, such as lotteries and roulette, in decisions among friends when other methods run into problems, in scientific research (e.g., for drug testing or to decide between competing empirical models) or in admission to university. But random mechanisms have also been used in the political realm. Firstly, they can be used as a strategy to make decisions. An important example is conscription for military service. In the 1970s, the U.S. government, for instance, used a lottery based on birthdays to determine which men were drafted into the army in order to fight in Vietnam. Draft lotteries were also used during World Wars I and II, both in the United States and in several European countries. Every eligible man should have an equal probability of being chosen.

Secondly, random mechanisms can be used as a strategy to choose decision makers. The best-known example today is the choice of persons to form a jury in serious criminal cases, such as murder, but sometimes also in civil cases. Criminal juries are of major importance in Anglo-Saxon countries, but also exist on the European continent, especially in Scandinavia. While professional judges are certainly more knowledgeable, the major reason to randomly select jurors is in order that justice be perceived as fair. Persons drawn by chance

\footnotetext{
19 There has been an extensive discussion on the use of the random mechanism in politics. See Elster (1989:chap.II) and Carson and Martin (1999). They also refer to much additional literature.
} 
Making International Organizations More Democratic / 321

from the whole population are seen to be, on average, more honest than some professional judges, and to reflect more closely the moral standards of the population. Moreover, fairness may lie in being heard and judged by ordinary people drawn from the whole population. ${ }^{20}$

The past has known important cases in which random selection has been used. Classical democracy in Athens in the fifth and fourth century B.C., which is still a model for today, used random selection as a central feature (Manin, 1997; Hansen, 1991; Engelstad, 1989). The Assembly, which every one of the between 30,000 and 60,000 citizens could attend, took the most important decisions. Its business was prepared by the Council of 500 members, composed of 10 groups of 50 members each. Each group was chosen by lot from one of the ten tribes of Athens. Each group took a turn as the Committee (prytany), and the order in which this was done was determined by lot. The persons presiding over the Assembly, the Council and the Committee were chosen by lot on the day they met. In addition, most public officials were chosen randomly. The only exception was when competence was considered fundamental for a particular office, such as the military officers and financial officials who were elected. Moreover, not all citizens could become randomly selected officials. They had, for instance, to be at least thirty years old. They were also subject to an assessment when selected, as well as at the end of their respective terms of office.

It is likely that other ancient Greek city-states used similar random mechanisms to select their politicians and public officials, but little is known about the respective rules. But random choice is well documented for medieval Italian city-states. It played a large role, particularly in Florence between 1328 and 1530, where the six to 12 members of the city government (whose terms were quite short, sometimes being only of two months' duration) were chosen by lot from the volunteers running for office. Their ability to do the job was scrutinized by a group of aristocrats and citizens. The latter were again selected by lot. Random mechanisms were also extensively used in other Italian citystates, such as Bologna, Parma and Vicenza, as well as in Barcelona. It was used in Venice until the city's independence was terminated by Napoleon in 1797. The selection process for the doge was very complex and, at each stage, involved random elements (Knag, 1998). First, 30 members of the Great Council, composed of several hundred members, were selected randomly and then reduced to nine by another draw. These persons elected a new group of 40 , which in turn were reduced to 12 by yet another draw. These 12 persons in

\footnotetext{
${ }^{20}$ In reality, neither the draft nor juries are chosen in a perfectly random way (Carson and Martin, 1999:20-21, 26-30; Elster, 1989:93-103).
}

DOI: $10.2202 / 1555-5879.1018$ 
turn elected a new group of 25 , which was again reduced by a random mechanism to nine. This was repeated several times. Only then did a group of 41 , none of whom could have been chosen previously, elect the doge. In the 1900s in San Marino, a similar procedure was used to select the state's two governors from the 60-member council (Carson and Martin, 1999:33).

\subsection{Proposals USING RANDOM SELECTION}

In the scholarly literature, many suggestions have been made to use random mechanisms for social decision-making because of their attractive features. It is sufficient to refer to some examples that are directly relevant for the proposal advanced here.

Random dictator. Out of the total electorate, one person is chosen by lot to act as a dictator for a specified period of time. This proposal seems to be rather awkward, but there are some good arguments in its favor (Elster, 1989:86-91). Random election is the only system which does not make it in peoples' interest to misrepresent their preferences (in particular by appearing to be more honest and less egoistic than they in fact are). In contrast, all elections provide an incentive to the contenders to present a too-favorable image of themselves to the voters. Another advantage is that the institution of a random dictator selects an "ordinary," representative member of the citizenry, and thus prevents professional politicians with their special interests from taking over. These advantages are also directly relevant for the random selection of citizens in charge of international organizations.

The institution of a random dictator also has some obvious disadvantages. The persons chosen as temporal dictators have no opportunity to learn from experience. The public bureaucracy, with its long and extensive experience, tends to accumulate considerable power and, when taken to the extreme, can dominate the citizens selected. In contrast to selection by lot, regular elections and re-elections have the advantage of making the incumbents accountable to the voters. As was already taken into account in the classical Athenian

democracy, random selection is inefficient in those areas of governance where the office holders have to exhibit special competence.

Probability Voting. Random selection can be combined with voting on issues. In the simple case of there being two alternatives, a vote is taken and the winner is then determined by using a random mechanism, whereby alternatives are attributed probabilities according to the percentage of votes they received. If alternative $\mathrm{A}$ receives $70 \%$ of the votes (and seven red balls), and B 30\% (and three blue balls), then alternative $\mathrm{A}$ is chosen if, for example, a random draw from a receptacle with the ten balls results in the selection of a red ball. If 
a blue ball is randomly drawn, alternative B is the winner (Frey, 1969; Intriligator, 1973).

Voting by Veto. In this decision-making system (Mueller, 1978), each person puts forward one alternative, and there is also the status quo alternative. In each round of voting, one voter can veto one of the alternatives. The sequence in which the voters can act in this way is determined by lot. Whichever alternative remains, i.e. is not vetoed by anyone, is the winner.

Random Selection in a Representative Democracy. From the voting populace, a random sample is chosen to form a national legislature (Mueller et al., 1972). Selection is through stratified sampling in order to ensure the representation of people with certain characteristics, as well as to prevent the overrepresentation of minority preferences. There is no stratified geographic sampling, as one goal of the proposal is to overcome pork barrel activities.

\section{COMPARISON TO OTHER PROPOSALS}

We have already argued that a global government ${ }^{2}$ is undesirable, inefficient and utopian. It need not be further discussed here.

A less extreme idea is to enlarge and improve on the existing United Nations. There have been many suggestions to reform the United Nations (see, e.g., Bertrand (1997) and for overviews Ghebali (1997) and Hüfner and Martens (2000)). The latest report on the United Nations and collective security comes from a panel set up by UN secretary-general Kofi Annan (2004); however, as outlined in section 2.4 on the reform of the Security Council, the proposals in general do not aim at a direct relationship to the citizens of the countries for whose interests the UN claims to work. Thus the voice of the citizens is completely missing as compared to the large number of professional politicians, diplomats, experts and public officials engaged.

Another proposal for the improvement of international relations seeks to integrate non-state actors into the decision-making process, most importantly the international non governmental organizations (INGOs), the transnational corporations and business NGOs (BINGOs). Their number today is estimated to be no less than 25,000, while in the 1950s it was just 1,000 (Keohane and Nye, 2000; Arts, 2003). This system is based on bargaining among these organized groups. It has the following problems:

\footnotetext{
${ }^{21}$ See, e.g., the proposals by Archibugi et al. (2000), Falk and Strauss (2001), Höffe (1999) or Galtung (2000).
}

DOI: $10.2202 / 1555-5879.1018$ 
- Many important interests are not organized in any effective way and are not part of this bargaining system. They also lose out compared to the wellorganized international NGOs.

- The INGOs are not democratically legitimized; there is no established relationship to the citizens.

- The outcomes of bargaining are uncertain and tend to favor the monied interests. While the 'logrolling' that takes place tends to lead to Paretosuperior outcomes for those in the winning coalition, those groups which are not a part of it tend to lose out.

- Many INGOs are inefficient and wasteful. It has therefore been suggested that there is a great need to subject them to auditing (The Economist, Sept. 20, 2003).

Yet another proposal for improving global governance is to give more importance to experts. They can be organized in groups in order to increase the amount of media attention they get. This is the road pursued, for instance, by the Club of Rome, the World Economic Forum, or the Copenhagen Consensus. With the expansion of the Internet, there are increasingly informal international networks. Such initiatives are well suited to make the views of specialists and/or highly engaged persons heard, but they are not democratically legitimized. They thus do not meet a crucial element of our own proposal.

Another new way of organizing global governance is the idea of Functional, Overlapping, Competing Jurisdictions (FOCJ). ${ }^{22}$ It supports the emergence of new governmental units according to the needs arising. The geographical size of a FOCUS is established according to its functional needs, and therefore differs greatly between areas. Some FOCJ will be very large and even cover the whole world (for instance, in the case of global warming or the regulation of outer space), but they may also be very small (for instance, in the case of local public goods, such as sanitation). FOCJ are not part of the nation-state; rather they tend to overlap each other. When they exist and grow in importance, the traditional nation-states will be reduced to those functions they are more efficiently providing than a newly emerging functional unit. FOCJ are conceived to be democratic. They can take recourse to random selection in

\footnotetext{
22 See, more fully, Frey and Eichenberger (1999) and Eichenberger and Frey (2002), and critical discussion by Vanberg (2000) and Blatter and Ingram (2000). FOCJ seem to be able to solve the trilemma discussed by Rodrik (2000), as they are able to align governmental jurisdictions with markets (but it should be noted that Rodrik envisages a World Government).
} 
Making International Organizations More Democratic / 325

order to ensure that the citizens can effectively make their demands known and control the management. FOCJ are thus consistent with the ideas proposed here.

\section{CONCLUDING REMARKS}

World governance today is characterized by international organizations short of democratic legitimacy. Professional politicians, diplomats, experts and public officials determine their behavior without much, or any, control by the citizens they claim to represent. As a consequence, international organizations have become the object of large-scale violent protests. At the same time, international organizations are criticized as being inefficient and wasteful.

This paper proposes an approach to world governance based on the democratic idea of citizen participation: From the citizenry of the member countries of an international organization, a random selection of people would be chosen to have the actual right to participate in international organization decision-making via initiatives, referendums and recalls. While this proposal would fundamentally change world governance compared to today, it would be restricted to improving the working of international organizations. The objective is to aim for four major improvements: First, selected citizens' access to initiatives, referendums, and recalls would give them effective means with which to control executive politicians and public officials in international organizations and thus reduce inefficiencies. Second, the introduction of direct democratic mechanisms for decision-making would give NGOs a constitutional instrument to pursue their goals. However, it would also force them to use procedures provided by law and would thus weaken them relative to latent groups (like taxpayers), which would be empowered. Third, international organizations would be connected to the people on behalf of whose interests they are expected to act. This would give citizens back some of the autonomy and self-determination they enjoy in democracy. Fourth, decisions in international organizations, which are approved by randomly selected citizens, would gain legitimacy and would be more likely to obtain acceptance (even if they are against the short term interests of national governments). This would be important due to the almost complete lack of direct enforcement mechanisms in the international realm.

The proposal is certainly in a preliminary stage and many aspects need further consideration. But one thing can be predicted with certainty: The decisionmakers in international organizations and national governments will reject it. While the basic thrust of an increased democratic element is difficult to deny, the proposal will be labeled naive and impossible to realize. But such a reaction

DOI: $10.2202 / 1555-5879.1018$ 
would correspond exactly to the interests of these decision-makers. They know that introducing randomly selected citizens would reduce their discretionary power and importance. It would therefore be in their interests to find as many arguments against the proposal as possible. Quite another strategy would be to simply ignore the proposal. In any case, the entrenched persons and groups will not support it. But this does not necessarily mean that it will never be put into practice, at least for some particular or newly founded international organizations.

\section{References}

Annan, Kofi. 2004. "Courage to Fulfill Our Responsibilities," 373(8404) The Economist December 4, 23-25.

Archibugi, Daniela, Sveva Balduini, and Marco Donati. 2000. "The United Nations as an Agency of Global Democracy," in Barry Holden, ed. Global Democracy. London: Routledge.

Arts, Bas. 2003. "Non-State Actors in Global Governance," Preprints, Max-PlanckProjektgruppe Recht der Gemeinschaftsgueter, Bonn.

Barnett, Michael N., and Martha Finnemore. 1999. "The Politics, Power and Pathologies of International Organizations," 53 International Organization 699732.

Benz, Matthias, and Alois Stutzer. 2004. "Are Voters Better Informed When They Have a Larger Say in Politics? Evidence for the European Union and Switzerland," 119(1-2) Public Choice 31-59.

Bertrand, Maurice. 1997. "Working Paper on the Establishment of a 'CharterObjective' Project for a New World Organization," in Maurice Bertrand and Daniel Warner, eds. A New Charter for a Worldwide Organisation? The Hague: Kluwer Law International, 45-66.

Blatter, Joachim, and Helen Ingram. 2000. "States, Markets and Beyond: Governance of Transboundary Water Resources," 40 Natural Resources Journal 439-73.

Bohnet, Iris, and Bruno S. Frey. 1999. "The Sound of Silence in Prisoner's Dilemma and Dictator Games," 38(1) Journal of Economic Behavior and Organization 43-57.

Bowler, Shaun, and Todd Donovan. 1998. Demanding Choices: Opinion, Voting, and Direct Democracy. Ann Arbor: University of Michigan Press.

Brady, Gordon L. 2003. "International Governance of the Internet: An Economic Analysis," 23(2) Economic Affairs 40-44.

Brennan, Geoffrey, and James M. Buchanan. 1980. The Power to Tax: Analytical Foundations of a Fiscal Constitution. Cambridge: Cambridge University Press. and 1985. The Reason of Rules. Constitutional Political Economy. Cambridge: Cambridge University Press.

Buchanan, James M., and Gordon Tullock. 1962. The Calculus of Consent. Logical Foundations of Constitutional Democracy. Ann Arbor: University of Michigan Press. 
Making International Organizations More Democratic / 327

Carson, Lyn, and Brian Martin. 1999. Random Selection in Politics. Westpoint, Conn. and London: Praeger.

Commission on Global Governance. 1995. Our Global Neighborhood. Oxford: Oxford University Press.

Cooter, Robert D. 2000. The Strategic Constitution. Princeton, NJ: Princeton University Press.

Dahl, Robert A., and Charles E. Lindblom. 1953. Politics, Economics and Welfare: Planning and Politico-Economic Systems Resolved into Basic Social Processes. Harper: New York.

Dollar, David, and Aart Kraay. 2004. "Trade, Growth, and Poverty," 114(493) Economic Journal F22-49.

Eichenberger, Reiner, and Bruno S. Frey. 2002. "Democratic Governance for a Globalized World," 55(2) Kyklos 265-88.

Elster, Jon. 1989. Solomonic Judgements. Cambridge: Cambridge University Press.

Engelstad, Fredrik. 1989. "The Assignment of Political Office by Lot," 28(1) Social Science Information 23-50.

Erez, Edna. 1985. "Random Assignment, the Least Fair of Them All: Prisoners' Attitudes Toward Various Criteria of Selection," 23(2) Criminology 365-79.

Falk, Richard, and Andrew Strauss. 2001. "Toward Global Parliament," 80 Foreign Affairs 212-220.

Frey, Bruno S. 1969. "Wahrscheinlichkeit als gesellschaftliche Entscheidungsregel," 21 Wirtschaft und Recht 14-26. 1983. Democratic Economic Policy. Oxford: Blackwell. . 1984. International Political Economics. Oxford and New York: Basil Blackwell. . 1997a. "A Constitution for Knaves Crowds Out Civic Virtues," 107(443) Economic Journal 1043-1053. 1997b. Not Just for The Money. An Economic Theory of Personal Motivation. Cheltenham, UK and Brookfield, USA: Edward Elgar. - (ed.) 1997c. Political Business Cycles. Cheltenham, UK: Edward Elgar. . 1997d. "The Public Choice of International Organizations," in Dennis C. Mueller, ed. Perspectives on Public Choice: A Handbook. Cambridge, New York and Melbourne: Cambridge University Press, 106-23.

Matthias Benz, and Alois Stutzer. 2004. "Introducing Procedural Utility: Not Only What, but also How Matters," 160(3) Journal of Institutional and Theoretical Economics 377-401.

and Reiner Eichenberger. 1999. The New Democratic Federalism for Europe: Functional, Overlapping and Competing Jurisdictions. Cheltenham, UK: Edward Elgar.

and Beat Gygi. 1990. "The Political Economy of International Organizations," 45(3) Aussenwirtschaft 371-94. and _. 1991. "International Organizations from the Constitutional Point of View," in Roland Vaubel and Thomas D. Willett, eds. The Political Economy of International Organizations: A Public Choice Approach. Boulder and Oxford: Westview Press, 58-78.

DOI: $10.2202 / 1555-5879.1018$ 
and Werner W. Pommerehne. 1993. "On the Fairness of Pricing - An Empirical Survey among the General Population," 20(3) Journal of Economic Behavior and Organization 295-307. and Alois Stutzer. 2000. "Happiness, Economy and Institutions," 110(446) Economic Journal 918-38.

and _ 2005. "Beyond Outcomes: Measuring Procedural Utility," 57(1) Oxford Economic Papers 90-111. and _. 2006. "Direct Democracy: Designing a Living Constitution," forthcoming in Roger Congleton and Birgitta Swedenborg, eds. Democratic Constitutional Design and Public Policy, Analysis and Evidence. Cambridge: MIT Press.

Galtung, Johan. 2000. "Alternative Models for Global Democracy," in Barry Holden, ed. Global Democracy. London: Routledge.

Gerber, Elisabeth R., and Simon Hug. 2001. "Legislative Response to Direct Legislation," in Matthew Mendelsohn and Andrew Parkin, eds. Referendum Democracy. Citizens, Elites and Deliberation in Referendum Campaigns. New York: Palgrave, 88-108.

Ghebali, Victor-Yves. 1997. "United Nations Reform Proposals Since the End of the Cold War: An Overview," in Maurice Bertrand and Daniel Warner, eds. $A$ New Charter for a Worldwide Organisation? The Hague: Kluwer Law International, 79-111.

Glasius, Marlies, Mary Kaldor, and Helmut Anheier (eds). 2002. Global Civil Society 2002. Oxford: Oxford University Press.

Hansen, Mogens Herman. 1991. The Athenian Democracy in the Age of Demosthenes: Structure, Principles and Ideology. Oxford: Basil Blackwell.

Held, Dieter. 1997. Democracy and the Global Order: From the Modern State to Cosmopolitan Governance. Cambridge: Polity Press.

Héritier, Adrienne (ed.). 2002. Common Goods. Reinventing European and International Governance. Lanham, MD: Rowan and Littlefield.

Hewson, Martin, and Timothy Sinclair (eds.). 1999. Approaches to Global Governance Theory. Albany, NY: State University of New York Press.

Hirschman, Albert O. 1970. Exit, Voice and Loyalty. Cambridge, MA: Harvard University Press.

Höffe, Otfried. 1999. Demokratie im Zeitalter der Globalisierung. München: C.H. Beck.

Hüfner, Klaus, and Jens Martens. 2000. UNO-Reform zwischen Utopie und Realität. Vorschläge zum Wirtschafts- und Sozialbereich der Vereinten Nationen. Frankfurt am Main: Lang.

Hunter, Dan. 2003. "ICANN and the Concept of Democratic Deficit," 36 Loyola of Los Angeles Law Review 1149-1183.

Intriligator, Michael D. 1973. "A Probabilistic Model of Social Choice," 40(4) Review of Economic Studies 553-60.

Kahler, Miles, and David A. Lake (eds). 2003. Governance in a Global Economy: Political Authority in Transition. Princeton: Princeton University Press. 
Making International Organizations More Democratic / 329

Kaul, Inge, Pedro Conceicao, Katell Le Goulven, and Ronald U. Mendoza (eds). 2003. Providing Global Public Goods. Managing Globalization. New York and Oxford: Oxford University Press.

Keane, John. 2003. Global Civil Society? New York: Cambridge University Press.

Keohane, Robert O. 2001. "Governance in a Partially Globalized World," 95(1) American Political Science Review 1-13. and Joseph S. Nye. 2000. Governance in a Globalized World. Washington D.C.: Brookings.

Kirchgässner, Gebhard, Lars Feld, and Marcel R. Savioz. 1999. Die direkte Demokratie: Modern, erfolgreich, entwicklungs- und exportfähig. Basel et al.: Helbing and Lichtenhahn/ Vahlen/ Beck.

Knag, Sigmund. 1998. "Let's Toss for It: A Surprising Curb on Political Greed," 3(2) Independent Review 199-209.

Manin, Bernard. 1997. The Principles of Representative Government. Cambridge: Cambridge University Press.

Matsusaka, John G. 2004. For the Many or the Few: The Initiative, Public Policy, and American Democracy. Chicago: University of Chicago Press.

McKelvey, Richard D. 1976. "Intransitivities in Multidimensional Voting Models and Some Implications for Agenda Control," 12 Journal of Economic Theory 472-82.

Mueller, Dennis C. 1978. "Voting by Veto," 10(1) Journal of Public Economics 57-75. 1996. Constitutional Democracy. New York: Oxford University Press. 2003. Public Choice III. Cambridge: Cambridge University Press.

, Robert D. Tollison, and Thomas D. Willett. 1972. "Representative Democracy Via Random Selection," 12 Public Choice 57-68.

Nye, Joseph S., Jr., and John D. Donahue. 2001. Governance in a Globalizing World. Washington, DC: Brookings Institution Press.

Olson, Mancur. 1965. The Logic of Collective Action. Cambridge, MA: Harvard University Press.

Palfrey, John G. 2004. "The End of the Experiment: How ICANN's Foray into Global Internet Democracy Failed," Public Law Research Paper No. 93, Harvard Law School.

Pierre, Jon (ed). 2000. Debating Governance: Authority, Steering and Democracy. Oxford and London: Oxford University Press.

Pommerehne, Werner W., and Hannelore Weck-Hannemann. 1996. "Tax Rates, Tax Administration and Income Tax Evasion," 88 Public Choice 161-170.

Rodrik, Dani. 2000. "How Far Will International Economic Integration Go?" 14 Journal of Economic Perspectives 177-186.

Romer, Thomas, and Howard Rosenthal. 1978. "Political Resource Allocation, Controlled Agendas, and the Status Quo," 33(4) Public Choice 27-43.

Sally, David. 1995. "Conversation and Cooperation in Social Dilemmas-A Metaanalysis of Experiments from 1958 to 1992," 7(1) Rationality and Society 58-92.

Schulze, Günther G., and Heinrich W. Ursprung. 1999. "Globalisation of the Economy and the Nation State," 22 World Economy 295-352.

Sen, Amartya. 1999. Development as Freedom. New York: Anchor Books.

DOI: $10.2202 / 1555-5879.1018$ 
Torgler, Benno. 2003. "Direct Democracy Matters: Tax Morale and Political Participation," in National Tax Association Papers and Proceedings, Orlando, 2002. Washington, DC: National Tax Association.

Vanberg, Viktor J. 2000. "Functional Federalism: Communal or Individual Rights?" 53 Kyklos 363-86.

Vaubel, Roland, and Thomas D. Willett (eds). 1991. The Political Economy of International Organizations: A Public Choice Approach. Boulder and Oxford: Westview Press.

Verweij, Marco, and Timothy E. Josling. 2003. "Special Issue: Deliberately Democratizing Multilateral Organization," 16(1) Governance: An International Journal of Policy, Administration, and Institutions 1-21.

Walzer, Michael (ed). 1998. Towards a Global Civil Society. Providence: Berghahn.

Wortman, Camille B., and Vita C. Rabinowitz. 1979. "Random Assignment: The Fairest of Them All," 4 Evaluation Studies Review Annual 177-84. 